\title{
Bimbingan Teknis Pemanfaatan Media Sosial sebagai Strategi Promosi Rumah Kreatif untuk Meningkatkan Kunjungan Wisatawan
}

\author{
Putu Ngurah Rusmawan ${ }^{1}$, Auda Nuril Zavilah ${ }^{2}$,Jemi Cahya Adi Wijaya ${ }^{3}$ \\ Manajemen Bisnis Pariwisata, Politeknik Negeri Banyuwangi, Indonesia ${ }^{1,2,3}$ \\ Email : putungurahrusmawan@poliwangi.ac.id ${ }^{1}$ audanuril@ poliwangi.ac.id $^{2}$ jemi.cahya@ poliwangi.ac.id ${ }^{3}$
}

\begin{abstract}
Abstrak
Kegiatan seni dan budaya Rumah Kreatif Kampung Batara yang berlokasi di Desa Papring Kecamatan Kalipuro Kabupaten Banyuwangi, di dalam teknis pelaksanaan kegiatan promosinya masih menggunakan teknik konvensional dan belum maksimal, sehingga rumah kreatif belum dikenal secara luas. Oleh karena itu, para pengelola kegiatan di Rumah Kreatif Kampung Batara harus diberikan pelatihan tentang cara dan pemanfaatan media sosial agar strategi promosinya bisa maksimal dan minat kunjungan wisatawan menjadi banyak. Pendekatan pelatihan yang digunakan dalam pelaksanaan PKM yaitu dengan memberikan pelatihan berupa ceramah dan tutorial. Agar pendidikan dan pelatihan yang disajikan interaktif dan efektif, PKM ini menggunakan pendekatan diskusi interaktif. Teknik yang digunakan adalah berbagi pendapat, diskusi kelompok, role play dan simulasi. Dengan cara seperti ini, diharapkan peserta menjadi termotivasi dan tidak mudah lelah serta bosan. Selain itu, pengelola akan didampingi dalam membuat akun media sosial yaitu Facebook dan Instagram serta cara mengoptimalkan penggunaan media sosial tersebut. Tim dosen MBP Politeknik Negeri Banyuwangi telah menyusun materi strategi promosi melalui media sosial secara ringkas agar mudah dipahami oleh pengelola Rumah Kreatif Dusun Papring. Materi pelatihan dibuat lebih sederhana dengan gambar memudahkan pengelola untuk memahaminya. Hasil kegiatan pendampingan PKM ini diharapkan dapat terus dilaksanakan dan dikembangkan oleh pendiri Rumah Kreatif Kampung Batara.
\end{abstract}

Kata kunci : media sosial, rumah kreatif, strategi promosi

\section{Abstract}

The artistic and cultural activities of the Batara Village creative house located in Papring Village, Kalipuro District, Banyuwangi Regency, in the technical implementation of promotional activities still use conventional techniques and have not been maximized, so that creative houses are not widely known. Therefore, the managers of activities at the creative house of Kampung Batara should be given training on how to use social media so that the promotion strategy can be maximized and the interest of tourist visits to be a lot. The training approach used in the implementation of PKM which was to provide training in the form of lectures and tutorials. The education and training presented to be interactive and effective, this PKM uses an interactive discussion approach. The techniques used are: sharing opinion, group discussion, role play and simulation. In this way, participants are expected to be motivated and not easily tired and bored. In addition, managers will be assisted in creating social media accounts, they are Facebook and Instagram and how to optimize the use of social media. MBP lecturer team of Politeknik Negeri Banyuwangi has compiled a brief promotional strategy material through social media so that it is easily understood by the manager of the creative house of Papring hamlet. The training material is made simpler with pictures making it easier for managers to understand. The results of this PKM mentoring activity are expected to continue to be implemented and developed by the founders of the Batara Village Creative House.

Keywords : social media, creative house, promotion strategy

Copyright (c) 2021 Putu Ngurah Rusmawan, Auda Nuril Zazilah, Jemi Cahya Adi Wijaya

$\triangle$ Corresponding author

Address : Politeknik Negeri Banyuwangi

Email : putungurahrusmawan@poliwangi.ac.id

DOI : https://doi.org/10.31004/abdidas.v2i4.394

ISSN 2721- 9224 (Media Cetak)

ISSN 2721- 9216 (Media Online) 
929 Bimbingan Teknis Pemanfaatan Media Sosial Sebagai Strategi Promosi Rumah Kreatif Untuk Meningkatkan Kunjungan Wisatawan - Putu Ngurah Rusmawan, Auda Nuril Zazilah, Jemi Cahya Adi Wijaya

DOI: https://doi.org/10.31004/abdidas.v2i4.394

\section{PENDAHULUAN}

Kampung Batara adalah tempat berkumpulnya anak-anak rimba hutan di kaki Gunung Raung, Kecamatan Kalipuro yang dijadikan sebagai pusat kegiatan untuk mengasah kreativitas. Mereka juga disebut anak rimba. Setiap musim tanam, mereka akan berjaga di hutan agar tanaman tidak dirusak babi hutan (Rahmawaty, 2016). Keberadaan Kampung Batara ini menjadi tempat berkumpul untuk sesekali meluangkan waktu sambil belajar di luar sekolah. Belajar berbagai jenis kesenian tradisional osing sambil bermain bersama alam di sekitar mereka. Mereka juga tetap melakukan proses belajar mengajar di sekolah terdekat.

Rumah Kreatif Kampung Batara tidak hanya menjadi tempat belajar, namun juga menjadi tempat bermain, beraktivitas, berlatih seni, dan budaya. Mayoritas penduduk di kampung ini merupakan petani dengan memanfaatkan sistem pertanian tumpang sari di hutan. Anak-anak rimba ini telah terbiasa keluar masuk hutan untuk menjaga tanaman mereka. Kini, anak-anak rimba hutan kaki Gunung Raung memiliki Rumah Bambu sebagai wadah kreativitas (Husdinariyanto 2021).

Rumah Bambu tersebut seluruh bahannya terbuat dari bambu. Melihat potensi Kelurahan Papring yang banyak bambunya, menjadikan tempat ini selaras dijadikan sebagai Rumah Bambu. Oleh karena itu, dikenal sebagai panggone pering (tempatnya bambu). Rumah Bambu, anak-anak di kampung ini menampilkan berbagai seni tradisi. Mulai dari pencak silat, barong, tari, memainkan musik tradisi, dan lainnya. Satu anak bisa memainkan berbagai seni. Ini membanggakan.

Lokasi Kampung Batara atau Kampung Baca Taman Rimba terletak di tepi hutan, lingkungan Papring, Kelurahan Kalipuro, Kecamatan Kalipuro, Kabupaten Banyuwangi. Kampung ini terletak sekitar 15 kilometer dari Kota Banyuwangi, dan berada di ketinggian 1000 meter dari permukaan laut.

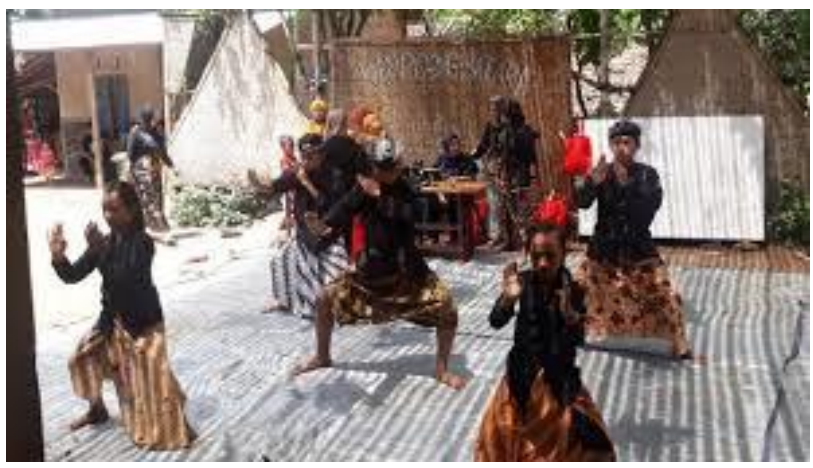

Gambar 1. Rumah Kreatif Kampung Batara

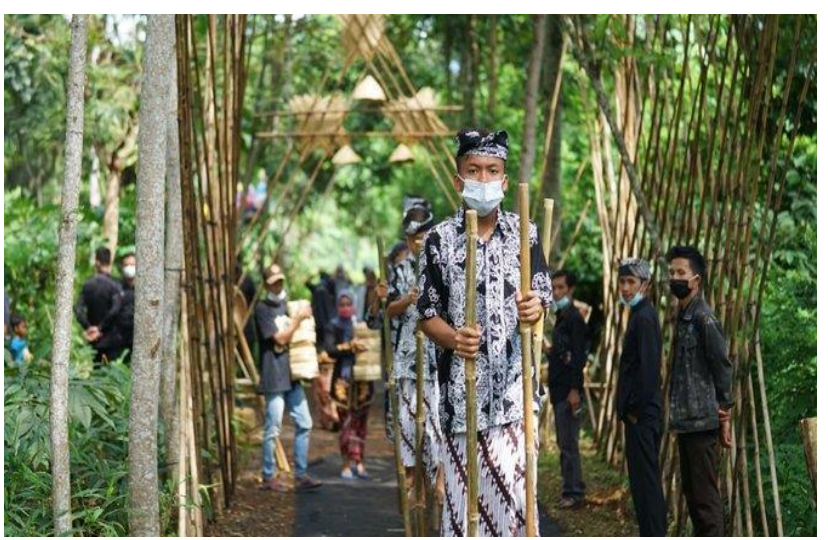

Gambar 2. Kegiatan Seni Budaya

Di sisi promosi, Rumah Kreatif Kampung Batara ini belum dikenal secara luas oleh wisatawan. Hal ini dikarenakan sistem pemasarannya yang masih minim dan konvensional. Promosi hanya dilakukan oleh perorangan saja kepada warga lain dalam lingkup kabupaten saja. Hal ini menjadikan 
930 Bimbingan Teknis Pemanfaatan Media Sosial Sebagai Strategi Promosi Rumah Kreatif Untuk Meningkatkan Kunjungan Wisatawan - Putu Ngurah Rusmawan, Auda Nuril Zazilah, Jemi Cahya Adi Wijaya

DOI: https://doi.org/10.31004/abdidas.v2i4.394

pengunjung wisatawan yang datang masih belum optimal. Padahal, Rumah Kreatif Kampung Batara ini dapat dijadikan wisata budaya dan adat.

Pertunjukan seni dan budaya di rumah kreativitas Desa Papring Kampung Batara dapat menjadi sumber perekonomian mereka. Hal inilah yang menjadi masalah yang dihadapi oleh petani pengelola rumah kreatif. Masalah ini jika dibiarkan terus menerus dapat menyebabkan tidak adanya lagi Rumah Kreatif Kampung Batara sebagai produk kearifan lokal khas Desa Papring dan tentunya akan menurunkan kesejahteraan warga.

Menyadari akan hal tersebut, maka sudah sepatutnya dilakukan perbaikan terhadap sistem promosi. Tentunya hal ini butuh pendampingan dari pihak lain agar pengelola Rumah Kreatif Kampung Batara tersebut mampu menjalankan promosi secara optimal. Dengan pendampingan, diharapkan Rumah Kreatif Kampung Batara dapat dikenal secara lebih luas lagi dan wisatawan yang datang dalam lingkup nasional bahkan mancanegara, mengingat kegiatan rumah kreatif di Kampung Batara

Melihat dari segi promosi, promosi Rumah Kreatif Kampung Batara masih sangat minim, bahkan dapat dikatakan belum ada strategi promosi yang memang dipersiapkan dan dilakukan. Wisatawan yang datang adalah yang dekat dan dalam lingkup desa sehingga minat kunjungan adalah untuk mengetahui kegiatan kreatif seni budaya di Rumah Kreatif Kampung Batara tersebut. Walaupun dapat ditemukan sesekali wisatawan yang datang dari luar daerah, akan tetapi wisatawan tersebut tidak datang ke Kampung Batara secara terus-menerus dikarenakan beberapa alasan yang bukan menjadi bagian dari sistem promosi.

Di sisi lain, sistem promosi yang masih minim ini juga diungkapkan oleh mitra dikarenakan pengelola Kampung Batara ini tidak mengetahui bagaimana cara mempromosikan kegiatan atraksi pertunjukan seni dan budaya Rumah Kreatif Kampung Batara dengan optimal karena terbatasnya kemampuan yang dimiliki dari segi promosi.

Canggihnya teknologi juga belum mampu dimanfaatkan dan digunakan oleh pengelola rumah kreatif karena belum mampunya mereka untuk mengoperasikannya dan mengelolanya. Padahal program Smart Kampung yang digadang-gadang oleh Pemerintah Kabupaten Banyuwangi sudah sangat mendukung untuk sistem promosi menggunakan digital marketing.

Di era sekarang ini, media sosial atau digital marketing menjadi bentuk promosi yang sangat optimal apabila digunakan dan dikelola dengan optimal. Tetapi, karena terbatasnya kemampuan dan pengetahuan maka hal ini tidak dimanfaatkan secara baik oleh pengelola. Tentu hal ini menjadi permasalahan utama yang dihadapi oleh mitra. Jika dibiarkan terus-menerus maka dikhawatirkan Rumah Kreatif Kampung Batara sebagai kearifan lokal Desa Papring ini menjadi terabaikan. Oleh karena itu, sistem promosi rumah kreatif Kampung Batara menjadi permasalahan utama yang diangkat dalam kegiatan pengabdian ini.

Prioritas permasalahan yang diangkat dalam kegiatan pengabdian ini adalah sistem promosi untuk meningkatkan kunjungan wisatawan. Hal ini dikarenakan pengelola usaha belum mengetahui tentang pentingnya promosi melalui digital 
931 Bimbingan Teknis Pemanfaatan Media Sosial Sebagai Strategi Promosi Rumah Kreatif Untuk Meningkatkan Kunjungan Wisatawan - Putu Ngurah Rusmawan, Auda Nuril Zazilah, Jemi Cahya Adi Wijaya

DOI: https://doi.org/10.31004/abdidas.v2i4.394

marketing secara optimal. Berdasarkan hal tersebut, maka terdapat dua solusi yang kami tawarkan.

Solusi yang pertama yaitu kami adakan pendampingan berupa ceramah tentang pentingnya promosi melalui digital marketing. Hal ini dimaksud agar pengelola memiliki wawasan tentang cara promosi yang optimal melalui digital marketing.

Solusi yang kedua yaitu kami akan berikan praktik langsung atau tutorial bagaimana menggunakan digital marketing. Pertama, kami akan tunjukkan bagaimana membuat akun untuk media sosial. Kedua, kami akan tunjukkan bagaimana mengelola akun tersebut. Ketiga, akan kami tunjukkan bagaimana cara promosi atau promosi melalui akun tersebut. Setelah itu, mitra akan kami dampingi saat mereka mempraktikkan sampai mereka sukses untuk dapat memasarkan melalui digital marketing.

\section{METODE}

Proses pengabdian ini dilakukan dalam beberapa tahapan, mulai dari koordinasi, persiapan sampai dengan selesainya kegiatan. Secara rinci tahapan kegiatan tersebut diuraikan pada penjelasan berikut.

a. Koordinasi dengan Mitra

Pada tahap ini, kami lakukan koordinasi dengan mitra untuk menentukan jadwal kegiatan, susunan kegiatan, lokasi kegiatan, dan peserta kegiatan. Kami koordinasikan jadwal yang tepat sehingga semua peserta dapat hadir dan memperoleh materi yang kami berikan. Peserta nantinya adalah pengelola Rumah Kreatif Kampung Batara. b. Persiapan

Tahap persiapan yaitu dimulai dengan menyiapkan materi yang akan dipaparkan. Kemudian materi tersebut akan dicetak untuk disebarkan kepada peserta saat kegiatan. Selain itu, tidak lupa juga dilakukan persiapan untuk pemateri yang tepat. Kemudian, persiapan lokasi dan alat pendukung seperti daftar hadir, konsumsi, dan lain lain akan dipersiapkan sebaik mungkin dalam tahap ini.

c. Pelaksanaan Pelatihan Sesi Pertama

Pada tahap ini, dilakukan pelatihan sesi pertama, yaitu ceramah tentangnya pentingnya penggunaan digital marketing sebagai strategi promosi. Para peserta akan diberikan materi oleh pemateri, kemudian dilanjutkan sesi tanya jawab dan diskusi.

d. Pelaksanaan Pelatihan Sesi Kedua

Pada tahap ini, dilakukan pelatihan sesi kedua, yaitu tutorial tentang penggunaan digital marketing, yaitu pembuatan akun media sosial, penggunaan akun dan pemanfaatan akun tersebut untuk promosi. Peserta akan kami dampingi sampai mereka bisa untuk mengoperasikan dengan baik.

e. Kontribusi Mitra

Dalam pelaksanaan kegiatan pengabdian ini, mitra berkontribusi dalam penentuan jadwal, lokasi dan peserta kegiatan. Mitra akan berkoordinasi dengan kami untuk menentukan jadwal yang tepat, lokasi yang cukup dengan memperhatikan protokol kesehatan yang ada, dan peserta yang akan mengikuti kegiatan ini. Dalam pelaksanaan kegiatan, mitra juga akan 
932 Bimbingan Teknis Pemanfaatan Media Sosial Sebagai Strategi Promosi Rumah Kreatif Untuk Meningkatkan Kunjungan Wisatawan - Putu Ngurah Rusmawan, Auda Nuril Zazilah, Jemi Cahya Adi Wijaya

DOI: https://doi.org/10.31004/abdidas.v2i4.394

membantu kami agar pelaksanaan kegiatan berjalan dengan baik dan optimal.

f. Langkah Evaluasi Pelaksanaan dan Keberlanjutan Program

Monitoring dan evaluasi bertujuan untuk melihat sejauh mana keberhasilan dari pelaksanaan program pengabdian masyarakat. Selain itu, monitoring dan evaluasi bertujuan untuk mengetahui apakah ditemukan masalah atau kendala yang mempersulit mitra sehingga program ini dapat berjalan dengan lancar dan bermanfaat untuk pengelola Rumah Kreatif Kampung Batara secara menyeluruh.

Langkah evaluasi pelaksanaan program diukur pada setiap kegiatan yaitu sebagai berikut :

1. Untuk memastikan sinkronnya peserta yang datang saat pelaksanaan, maka akan kami cek peserta yang datang dengan daftar hadir peserta yang telah ditandatangani.

2. Kami akan pastikan bahwa tiap peserta yang datang memiliki akun media sosial sesuai dengan apa yang kami jelaskan saat pelatihan serta akan kami data.

3. Selain itu, akan kami pantau juga bahwa peserta dapat menggunakan akun tersebut untuk memasarkan produk.

4. Kami sebarkan lembaran saran atau kritik yang akan diisi oleh peserta sebagai masukan bagi kami.

5. Untuk mengevaluasi keberlanjutan program, kami akan cek secara berkala akun media sosial yang telah kami data apakah akun tersebut aktif digunakan atau tidak.
6. Kami akan terus berkomunikasi dengan mitra untuk mengetahui kebermanfaat program kegiatan yang kami lakukan dan dampak bagi pengelola usaha.

\section{HASIL DAN PEMBAHASAN}

Tim dosen MBP Politeknik Negeri Banyuwangi telah menyusun materi strategi promosi melalui media sosial secara ringkas agar mudah dipahami oleh pengelola rumah kreatif Dusun Papring. Materi pelatihan dibuat lebih sederhana dengan gambar memudahkan pengelola untuk memahaminya. Pertimbangan tersebut dikarenakan saat survei ke lapangan pengelola banyak yang belum memahami rumah kreatif untuk strategi promosi melalui media sosial tentang bagaimana mempromosikan rumah kreatif untuk mendatangkan wisatawan baik lokal maupun internasional yang efektif dan praktis.

Strategi promosi yang digunakan dalam mengisi gambar menarik pada media sosial tentang kegiatan seni budaya yang dilakukan di Rumah Kreatif Papring seperti pada lampiran 2. Setelah pelatihan strategi promosi efektif dibuat kemudian dilakukan validasi dengan pengelola apakah sudah sesuai atau belum dengan materi yang diberikan. Materi dikemas sederhana dan rapi tak lupa dengan sedikit cerita motivasi yang menginspirasi.

\section{Proses Pendampingan Pelatihan}

Proses pelatihan yang direncanakan selama bulan Juli 2021 mengalami perubahan menjadi bulan J u ni 2021 dengan 2 kali proses pembelajaran yaitu proses pembelajaran level 1 di 
933 Bimbingan Teknis Pemanfaatan Media Sosial Sebagai Strategi Promosi Rumah Kreatif Untuk Meningkatkan Kunjungan Wisatawan - Putu Ngurah Rusmawan, Auda Nuril Zazilah, Jemi Cahya Adi Wijaya

DOI: https://doi.org/10.31004/abdidas.v2i4.394

Rumah Kreatif Kampung Papring tanggal 6 juni 2021 dikarenakan ada pembatasan kegiatan sosial PPKM di Banyuwangi mulai 3 juli sampai 20 juli 2021. Pelatihan strategi promosi melalui media sosial terdiri dari beberapa bagian yang pertama proses pengambilan gambar desain visual, kedua proses pembuatan akun sosial media, dan terakhir proses upload gambar dan video kegiatan seni budaya Rumah Kreatif Papring.

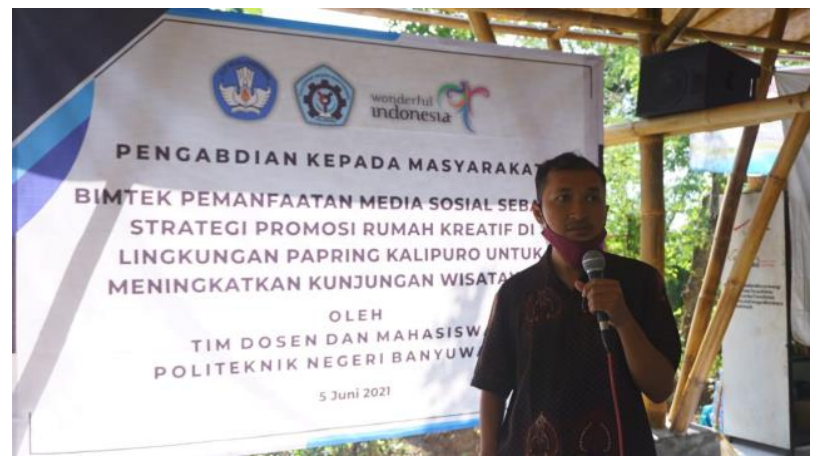

Gambar 3. Pemberian Pelatihan pada Pengelola

Agar pendidikan dan pelatihan yang disajikan interaktif dan efektif, PKM ini menggunakan pendekatan diskusi interaktif. Teknik yang digunakan adalah: berbagi pendapat, diskusi kelompok, role play dan simulasi. Dengan cara seperti ini, diharapkan peserta menjadi termotivasi dan tidak mudah lelah serta bosan. Materi pelatihan disesuaikan dengan jenis pilihan paket pelatihan:

1. Mengadakan penyampaian materi serta diskusi bersama peserta mengenai pengenalan dan pemanfaatan media sosial sebagai sarana untuk strategi promosi mendatangkan minat wisatawan.

2. Menyelenggarakan sesi tanya jawab untuk menjawab rasa keingintahuan para peserta pelatihan.
3. Memberikan simulasi terkait materi-materi yang telah disampaikan.

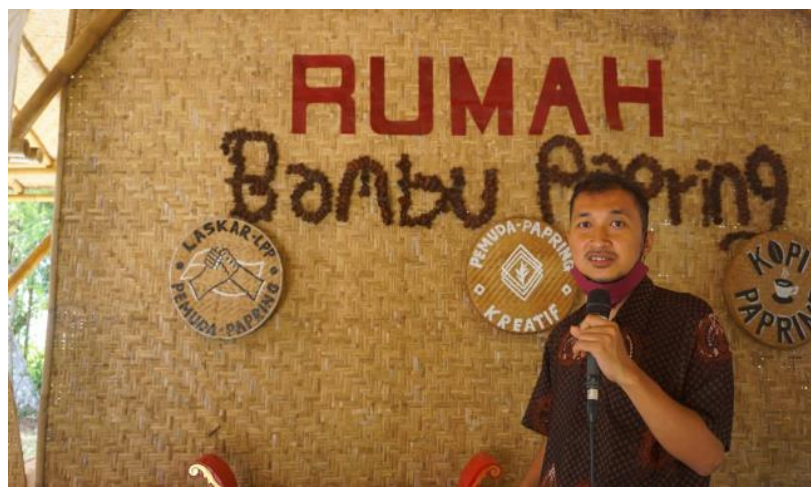

Gambar 4. Pemberian Tutorial Pemanfaatan Media Sosial

Di dalam pelaksanaan kegiatan ini kami melakukan perjalanan dari rumah dengan menggunakan kendaraan pribadi. Pada pelatihan ini, persiapan yang telah dilakukan selama satu bulan. Dalam perjalanan untuk mencapai lokasi, kami melakukan survei pra pelaksanaan untuk melihat persiapan yang akan dilakukan. Selanjutnya melakukan rapat penentuan persiapan pelaksanaan kegiatan pada hari pelaksanaan pelatihan dengan pengelola rumah kreatif. Dalam rapat ini, diputuskan mengenai kesiapan pelaksanaan pelatihan 100 persen.

Kegiatan ini dilaksanakan selama satu hari pada hari hari sabtu, 5 Juni 2021. Rumah kreatif Papring lokasinya dekat dengan destinasi Bukit Sewu Sambaing di mana detinasi tersebut mempunyai sisi keindahan yang dapat memukau bagi setiap pengujung wisatawan. Objek wisata tersebut menjadi daya tarik pengunjung jarang dijumpai wisatawan. Destinasi Bukit Sewusambang akan menjadi daya jual tersendiri. Pengelola Rumah Kreatif Papring harus cerdas dan cermat membaca 
934 Bimbingan Teknis Pemanfaatan Media Sosial Sebagai Strategi Promosi Rumah Kreatif Untuk Meningkatkan Kunjungan Wisatawan - Putu Ngurah Rusmawan, Auda Nuril Zazilah, Jemi Cahya Adi Wijaya

DOI: https://doi.org/10.31004/abdidas.v2i4.394

fenomena pada saat ini. Mereka dapat mempromosikan atau wilayahnya melalui media massa dan media sosial.

Pada saat pelaksanaan acara dimulai pukul 08.30 yang diawali dengan registrasi peserta yang dilakukan panitia. Dilanjutkan pembukaan dengan sambutan-sambutan pada 09.00-10.00 WIB. Sesi pertama, pada 10.00-11.30 WIB yaitu pemberian materi yang disampaikan pemateri. Pada materi ini disampaikan strategi promosi rumah kreatif dengan memanfaatkan media sosial. Dilanjutkan dengan coffee break dan shalat pada 11.30-12.30 WIB dengan santai, lalu dilanjutkan sesi kedua. Pada 12.30-14.00 WIB. Dengan pemateri kedua, tentang "Teknik Pengambilan Foto Destinasi Wisata yang Menarik sebagai Strategi Promosi Pada Wisatawan.”

Teknologi dan informasi yang semakin berkembang akan mendorong orang untuk menciptakan peluang-peluang yang sangat menguntungkan bagi pengelola destinasi wisata dengan pemanfaatan kemajuan teknologi dan informasi. Dalam tahap ini pengelola rumah kreatif diberikan pemahaman tentang pentingnya mempromosikan dan branding destinasi wisata yang menarik bagi wisatawan domestik maupun mancanegara. Pendekatan ini dilakukan dengan memberikan teori-teori yang berkaitan dengan pentingnya mempromosikan dan menarik wisatawan untuk untuk berkunjung melihat pagelaran seni budaya yang ada di lingkungan Papring. Dilengkapi dengan demonstrasi produk UKM unggulan Desa Papring seperti produk madu dan tanaman bambu.

Produk UKM telah memenuhi syarat keamanan dan kemanfaatan di mana bisa

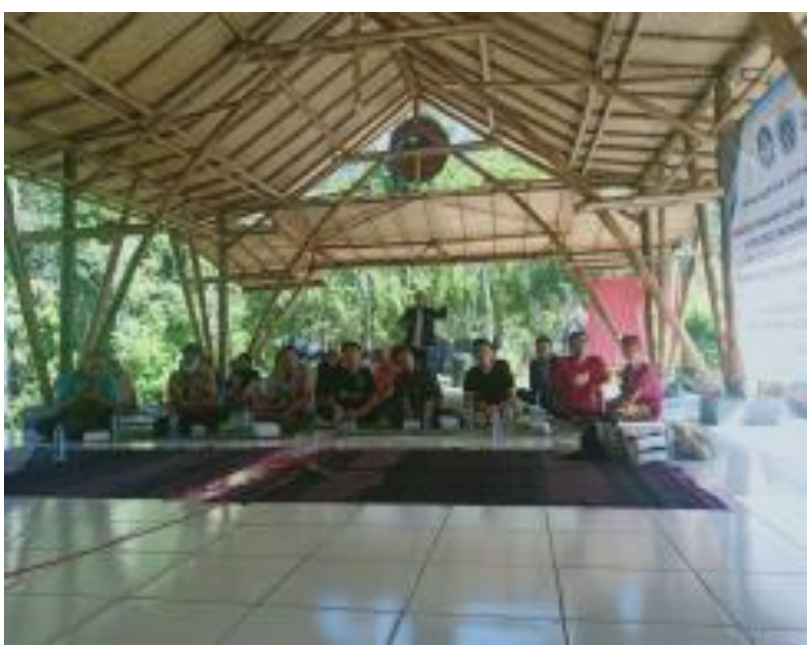

Gambar 6. Diskusi Stakeholders Rumah Kreatif Papring

Di era revolusi industri 4.0 ini semakin cepat dan terbukanya suatu informasi Yang di mana segala sesuatunya hanya dengan ketukan jari berita dapat mengakses informasi seluas luasnya bahkan pada era ini peran manusia dalam beberapa pekerjaan akan digantikan dengan teknologi untuk itu tim 
935 Bimbingan Teknis Pemanfaatan Media Sosial Sebagai Strategi Promosi Rumah Kreatif Untuk Meningkatkan Kunjungan Wisatawan - Putu Ngurah Rusmawan, Auda Nuril Zazilah, Jemi Cahya Adi Wijaya

DOI: https://doi.org/10.31004/abdidas.v2i4.394

dosen MBP Poliwangi beserta mahasiswanya secara serius mengerjakan PKM ini untuk secara bersama dapat membuka wawasan akan peluang peluang baru tentang perekonomian pariwisata. Pada hari Sabtu, tepatnya pukul delapan pagi pada saat tim dosen dan mahasiswa Poliwangi gelar pelatihan strategi promosi Rumah Kreatif Papring dengan memanfaatkan media sosial. Setelah dilakukan proses pelatihan strategi promosi Rumah Kreatif Papring dengan memanfaatkan media sosial, pengelola diminta memberikan tanggapan terhadap pelatihan yang telah dilaksanakan.

Hasil dari penyebaran kuesioner tersebut $85 \%$ pengelola senang dengan kegiatan tersebut karena dapat menambah pendapatan mereka dan juga yang hasil tersebut didukung oleh pernyataan pengelola. Menurutnya, sangat bermanfaat dengan dilaksanakannya kegiatan pelatihan strategi promosi Rumah Kreatif Desa Papring karena bisa dijadikan bekal ilmu bagi pengelola untuk memasarkan di tengah masyarakat. Dalam melaksanakan PKM ini dibutuhkan beberapa keahlian keterampilan untuk mendukung kegiatan pendampingan para pengelola diharapkan mampu melakukan inovasi terobosan sektor pengembangan ide kreatif di dalam mewujudkan rencana usahanya pada proses aktivitas.

\section{SIMPULAN}

Kegiatan pengabdian masyarakat yang telah dilaksanakan yaitu proses pelatihan strategi promosi Rumah Kreatif Papring telah berjalan dengan baik dan lancar. Proses pembuatan-pembuatan materi pelatihan dilakukan di Politeknik Negeri
Banyuwangi. Kegiatan yang dikembangkan telah memberikan motivasi kepada pengelola untuk mempelajari teknik strategi dengan memanfaatkan media sosial sebagai media promosi kegiatan seni budaya yang ada di lingkungan Desa Papring. Pihak mitra sangat senang adanya pengembangan kegiatan promosi yang dapat membantu pengelola mempelajari strategi promosi dan membuat pengelola senang dengan mulai ide kreatif promosinya. Serta pihak mitra mengharapkan proses pengembangan promosi yang luas.

\section{DAFTAR PUSTAKA}

Husdinariyanto, N. (2021). Bupati Ipuk resmikan Rumah Kampoeng Batara Banyuwangi [Halaman web] Diakses dari https://jatim.antaranews.com/berita/469234/bu pati-ipuk-resmikan-rumah-kampoeng-batarabanyuwangi

Kementerian Pariwisata dan Ekonomi Kreatif. (2020). Subsektor Ekonomi Kreatif.https://kemenparekraf.go.id/layanan/Su bsektor-Ekonomi-Kreatif. Diakses 1 April 2021

Pemerintah Kabupaten Banyuwangi. (2020). Rencana Strategis Perangkat Daerah Di Lingkungan Pemerintah Kabupaten Banyuwangi.

http://jdih.banyuwangikab.go.id/dokumen/perb up/Pebup_renstra_skpd_2020-2021.pdf.

Rachmawaty, I . (2016). Belajar Cerdas Tanpa Batas di kampung batara [Halaman web]Diakses dari https://regional.kompas.com/read/2016/10/25/1 1480061/belajar.cerdas.tanpa.batas.di.kampun g.batara.banyuwangi?page $=$ all

Rakhmat Supriyono. (2010). Desain Komunikasi Visual. Yogyakarta. Penerbit Andi 